Disclosure of Interests: Georgi Vasilev: None declared, Mariana Ivanova Goycheva Speakers bureau: Abbvie, Pfizer, UCB, Novartis, Ekaterina Ivanova-Todorova: None declared, Kalina Tumangelova-Yuzeir: None declared, Ekaterina Kurteva: None declared, Rumen Stoilov Speakers bureau: Abbvie, Pfizer, Amgen, UCB, Novartis, Dobroslav Kyurkchiev: None declared

DOI: 10.1136/annrheumdis-2019-eular.4643

\section{SAT0020 BLOOD RNA SEQUENCING REVEALS IMMUNOLOGICAL PROCESSES ASSOCIATED WITH THE RESPONSE TO ABATACEPT IN RHEUMATOID ARTHRITIS}

Antonio Julià ${ }^{1}$, Maria Lopez Lasanta ${ }^{1}$, Antonio Gómez ${ }^{1}$, Raimon Sanmarti ${ }^{2}$, Carlos Marras Fernandez $\mathrm{Cid}^{3}$, José Manuel Pina Salvador ${ }^{4}$, Susana Romero-Yuste ${ }^{5}$, Raul Maria Veiga Cabello ${ }^{6}$, Pilar Navarro ${ }^{7}$, Carme Moragues Pastor $^{8}$, Silvia Martinez Pardo ${ }^{9}$, Javier de Toro-Santos ${ }^{10}$, Amalia Sánchez $^{11}$, Dacia Cerda ${ }^{12}$ Alejandro Prada ${ }^{13}$, Alba Erra ${ }^{1}$, Jordi Monfort ${ }^{14}$, Ana Urruticoechea-Arana ${ }^{15}$, Núria Palau ${ }^{1}$, Raquel M. Lastra', Raül Tortosa ${ }^{1}$, Andrea Pluma Sanjurjo ${ }^{1}$, Sara Marsall ${ }^{1}$ Vall Hebron H, Barcelona, Spain; ${ }^{2} \mathrm{H}$ Clinic, Barcelona, Spain; ${ }^{3} \mathrm{H}$ Virgen Arrixaca, Murcia, Spain; ${ }^{4} \mathrm{H}$ Barbastro, Huesca, Spain; ${ }^{5} \mathrm{CHU}$ Pontevedra, Pontevedra, Spain; ${ }^{6}$ HUC de la Defensa Gómez Ulla, Madrid, Spain; ${ }^{7} \mathrm{HU}$ Fuenlabrada, Madrid, Spain; ${ }^{8} \mathrm{H}$ Platò, Barcelona, Spain: ${ }^{9} \mathrm{HU}$ Mutua Terrrassa, Terrassa, Barcelona, Spain; ${ }^{10}$ U A Coruña, La Coruña, Spain; ${ }^{11} \mathrm{HU}$ Lucus Augusti, Lugo, Spain; ${ }^{12} \mathrm{H}$ Moises Broggi, Sant Joan Despí, Barcelona, Spain; ${ }^{13} \mathrm{HU}$ Torrejón de Ardoz, Madrid, Spain; ${ }^{14} \mathrm{H}$ Del Mar, Barcelona, Spain; ${ }^{15} \mathrm{H}$ Can Misses, Ibiza, Spain

Background: Abatacept (CTLA4-Ig) is an approved biological therapy for the treatment of rheumatoid arthritis (RA). Similar to other biological agents, most patients $(60 \%)$ respond significantly to this therapy. To date, however, the biological mechanisms underlying the lack of efficacy for this drug are unknown.

Objectives: The objectives of the present study were to characterize the biological processes underlying the lack of efficacy of abatacept and to evaluate the blood transcriptome as a valid source for drug response prediction.

Methods: A total of $\mathrm{n}=57$ patients diagnosed with $\mathrm{RA}$ were recruited for this study from 16 rheumatology departments in Spain. All patients were $>18$ years old and, had $>6$ months of disease evolution. The primary clinical response to abatacept was defined at week 12 using the EULAR criteria. Good and moderate responders were aggregated into a single response group, and compared to the no response group of patients. Blood RNA was collected from all patients at baseline. From a subgroup of patients $(n=31)$, blood RNA was also obtained at weeks 12, 24 and 48 of treatment with abatacept. Gene expression levels were determined using paired-end RNA-seq (Illumina). Differential gene expression, association to biological processes, longitudinal association analysis and building of the multigenic predictor were performed using the $\mathrm{R}$ software and the specialized Bioconductor libraries. The the prediction accuracy was evaluated using the ROC AUC.

Results: From the 57 patients treated with abatacept, $n=10$ (17.5\%) were good EULAR responders, $n=24(42 \%)$ moderate EULAR responders and $\mathrm{n}=23(40.5 \%)$ non-responders at week 12 of therapy. Biological process analysis identified two significantly distinct biological profiles between responders and non-responders. In responders, we found an association to pathways associated with the effector phase of $T$ cells (e.g. interleukin-15 and 2 signalling, $P<0.05$ ). Non-responder patients showed instead a strong association to biological processes associated with antigen presentation and activation of $T$ cells $(P<0.005)$. Using the baseline gene expression profiles, we built a multigenic predictor of response to abatacept with an AUC $=75 \%$. In the longitudinal cohort, patients were stratified based on reaching an inactive state (i.e. DAS28 < 3.2). Using this endpoint measure, the longitudinal analysis of the 4 time points corroborated the association of response with antigen presentation $(P<0.01)$. Conclusion: The analysis of blood RNA profiles of RA patients has enabled the identification of specific biological processes associated with the lack of response to abatacept. Also, we demonstrate that blood expression profiles can be predictive of the response to the drug at week 12 of therapy.

Disclosure of Interests: Antonio Julià: None declared, Maria Lopez Lasanta: None declared, Antonio Gómez: None declared, Raimon Sanmarti Grant/research support from: Research support: Bristol-Myers Squibb, Speakers bureau: Speakers bureau: Bristol-Myers Squibb, Carlos Marras Fernandez Cid: None declared, José Manuel Pina Salvador: None declared, Susana Romero-Yuste: None declared, Raul Maria Veiga Cabello: None declared, Pilar Navarro: None declared, Carme Moragues
Pastor : None declared, Silvia Martinez Pardo: None declared, Javier de Toro-Santos: None declared, Amalia Sánchez: None declared, Dacia Cerda: None declared, Alejandro Prada: None declared, Alba Erra: None declared, Jordi Monfort Speakers bureau: Bioibérica

Procare Health, ANA URRUTICOECHEA-ARANA: None declared, Núria Palau: None declared, Raquel M Lastra: None declared, Raül Tortosa: None declared, Andrea Pluma Sanjurjo: None declared, Sara Marsal: None declared

DOI: 10.1136/annrheumdis-2019-eular.5389

\section{SAT0021 ELEVATED NUMBERS OF C-TYPE LECTIN CD161 POSITIVE PR3-SPECIFIC T-CELLS IN GPA}

Sebastian Klapa ${ }^{1,2}$, Anja Kerstein ${ }^{1}$, Andreas Koch ${ }^{2}$, Silke Pitann ${ }^{1}$, Relana Nieberding ${ }^{1}$, Gabriela Riemekasten ${ }^{1}$, Antje Müller ${ }^{1}$, Peter Lamprecht ${ }^{1}$. ${ }^{1}$ University of Lübeck, Clinic of Rheumatology and Clinical Immunology, Lübeck, Germany, ${ }^{2}$ Christian Albrechts University Kiel, Institute of experimental Medicine c/ o German Naval Medical Institute, Kronshagen, Germany

Background: Various alterations of the peripheral T-cell compartment have been reported in granulomatosis with polyangiitis (GPA) such as elevated populations of CD4+CD8+ double-positive and CD4+CD161+ and CD28- single-positive effector memory T-cells $\left(T_{E M}\right)$ within the total CD3+ T-cell population (1). Analysis of antigen-specific T-cell subpopulations shows, that PR3-specific T-cells display Th2-type, Th17 and Th22 cytokine profiles in GPA (2). Moreover, concomitant cellular CMV- and Epstein Barr virus (EBV)-infection has been found to be associated with the expansion of CD28- $T_{E M}$ in GPA $(1,2)$. Notably, C-type lectin CD161 +CD8+ T-cells displaying a polyfunctional memory profile directed against several common viruses have been reported. Furthermore, CD161+ Tcells are involved in the pathogenesis of early stage autoimmune hepatitis (3). CD161 expression on proteinase 3 (PR3)-specific T-cells in comparison to other antigen-specific T-cells has not been described in GPA as yet.

Objectives: To determine the amount of C-type lectin CD161 on antigenspecific CD8+ single-positive and CD4+CD8+ double positive T-cells in patients with GPA

Methods: In this study, we analyzed the expression of CD161 and CD28 on circulating antigen-specific CD8+ single-positive and CD4+CD8+ double positive T-cells in HLA-A2 positive patients with GPA $(n=21)$ and healthy controls $(n=21)$ using flow cytometry. Antigen-specific $T$ cells were detected using peptide/MHC class 1 dextramers containing major peptide epitopes for PR3, Epstein Barr virus (EBV) BMLF1, and Cytomegalovirus (CMV) pp65 (aa 196-177, aa 280-288, and aa 495-504, respectively).

Results: Patients with GPA showed a higher frequency of circulating CD8 + single-positive and CD4+CD8+double-positive PR3-specific T-cells with increased expressions of CD161 compared to HC. Compared to EBV- or CMV-specific T-cells, there was an increased expression of CD161 on PR3-specific T-cells in GPA. In contrast to HC and EBV- or CMV-specific T-cells, the percentage of CD28+ T-cells was expanded within the PR3specific CD8+ T-cell subset in GPA.

Conclusion: These findings suggest a potential role of CD161 as an additional TCR-independent co-stimulatory receptor on PR3-specific T-cells in GPA. The role of these cells in the pathophysiology and as a potential therapeutic target remains be further investigated.

\section{REFERENCES}

[1] Kerstein A, et al., Environmental factors and inflammation-driven alteration of the total peripheral T-cell compartment in granulomatosis with polyangiitis; J Autoimmun. 2017 Mar;78-79-91

[2] Lamprecht $P$, et al., Pathogenetic and clinical aspects of anti-neutrophil cytoplasmatic autoantibody associated vasculitis. Front. Immunol. 2018; 9:680

[3] Renand A, et al. Immune alterations in patinents with type 1 autoimmune hepatitis persist upon standard immunosuppressive treatment. Hepatol Commun. 2018 Aug 6;2(8):868-981

Disclosure of Interests: Sebastian Klapa: None declared, Anja Kerstein: None declared, Andreas Koch: None declared, Silke Pitann: None declared, Relana Nieberding: None declared, Gabriela Riemekasten Consultant for: Chugai, F. Hoffmann-La Roche, Speakers bureau: Chugai, F. Hoffmann-La Roche, Antje Müller: None declared, Peter Lamprecht: None declared

DOI: 10.1136/annrheumdis-2019-eular.6771 